\title{
PENINGKATAN KUALITAS MEMBACA DAN MENULIS SISWA SEKOLAH DASAR MELALUI STUDY CLUB
}

\section{Rostiena Pasciana ${ }^{*}$, Sifak Nur Fadlam Yusidha ${ }^{1}$, Andi Reksa Dzunurain Walyasa ${ }^{2}$, Citra Rahmayanti ${ }^{1}$, Wyno Nicky Laxmi ${ }^{1}$, Ieke Sartika Iriany ${ }^{1}$}

\author{
Fakultas Ilmu Sosial dan Ilmu Politik Universitas Garut ${ }^{1}$ \\ Fakultas Ekonomi Universitas Garut ${ }^{2}$ \\ Corresponding Author*: rostiena pasciana@fisip.uniga.ac.id
}

\begin{abstract}
The purpose of this program is to solve the problems that occur at SDN Sukarasa 2, the low of student's ability to read and write due to the impact of online learning during the Covid-19 pandemic. This program is based on student data collected and information from elementary school teachers regarding students who were not fluent in reading and writing. The object in this study were class 1, class 2, and class 3 students. The results of the study club learning method shows that this program can improve student's reading and writing skills.

Keyword: covid-19 pandemic; education; reading and writing; study club
\end{abstract}

\begin{abstract}
Abstrak
Tujuan kegiatan ini untuk membantu memecahkan permasalahan yang terjadi di SDN Sukarasa 2 yaitu kurangnya kemampuan siswa dalam membaca dan menulis yang merupakan dampak dari pembelajaran online/daring selama masa Pandemi Covid-19. Kegiatan ini dilakukan berdasarkan pada data siswa yang terhimpun serta informasi dari guru kelas SD akan adanya siswa yang belum lancar dalam membaca dan menulis. Sasaran dalam kegiatan ini ialah siswa kelas 1, kelas 2, dan kelas 3. Hasil dari adanya metode pembelajaran study club menunjukan bahwa kegiatan ini dapat membantu meningkatkan kemampuan siswa dalam membaca dan menulis.
\end{abstract}

Kata Kunci : Pandemi Covid-19; pendidikan; membaca dan menulis; study club

Copyright @ 2021, Rostiena Pasciana, dan kawan-kawan. This is an open access article under the CC-BY NC-SA license. http://DOI 10.30656/ps2pm.v3i2.4078 to this article

Rostiena Pasciana, dan kawan-kawan. Peningkatan Kualitas Membaca dan Menulis Siswa Sekolah Dasar melalui Study Club 


\section{PENDAHULUAN}

Pandemi Covid-19 membawa dampak yang sangat signifikan terhadap berbagai aspek kehidupan di tatanan masyarakat, dampak yang ditimbulkan begitu berat sehingga membuat apa yang menjadi kebiasaan di masyarakat berubah total (Pamungkas \& Sukarman, 2020). Salah satu aspek yang terdampak adalah bidang pendidikan, hal tersebut ditandai dengan adanya pemberhentian kegiatan pembelajaran di sekolah (Yusrizal et al., 2020). Terjadi perubahan besar dalam tatanan sistem pengajaran dunia pendidikan ketika pandemi Covid-19 mulai menyebar. Di negara Indonesia sendiri terjadi perubahan pola pengajaran, dari kegiatan belajar mengajar secara langsung (luring) menjadi pembelajaran secara daring/online (Ariesca et al., 2021). Pada umunya, kegiatan belajar secara online adalah kegiatan belajar yang dilaksanakan dengan memanfaatkan teknologi dan internet (Setiono et al.,
2020). Dalam pembelajaran secara daring/online diperlukan adanya kerja sama antara pengajar, pelajar dan orang tua (Handayani, 2020). Adanya pembelajaran daring ini dirasa paling efektif untuk semua tingkat sekolah, baik SD, SMP, maupun SMA. Sekolah Dasar merupakan awal kelas dasar sebagai bentuk dalam memberikan bekal/pemahaman dasar serta kemampuan baca-tulis-hitung, pengetahuan, dan keterampilan dasar bagi siswa yang disesuaikan dengan tingkat perkembangannya (Muhyidin et al., 2018). Kemampuan membaca dan menulis merupakan hal dasar yang perlu dikuasai karena dapat menjadi kunci agar peserta didik dapat paham terhadap isi materi pembelajaran (Alawiyah et al., 2018).

Berdasarkan PP No.57 Tahun 2021 tentang Standar Nasional Pendidikan menyatakan standar kompentensi pendidikan jenjang Pendidikan Dasar difokuskan pada penanaman karakter yang sesuai dengan nilai-nilai

Rostiena Pasciana, dan kawan-kawan. Peningkatan Kualitas Membaca dan Menulis Siswa Sekolah Dasar melalui Study Club 
Pancasila serta kompentensi literasi dan numerasi peserta didik (PPRI, 2021). Adanya pandemi Covid-19 khususnya di SDN Sukarasa 2 mengharuskan pembelajaran dilakukan menjadi daring/online, sehingga berdampak pada aspek perkembangan siswa baik itu dalam membaca maupun menulis. Hal ini berdampak sekali kepada siswa kelas 1, kelas 2 dan kelas 3. Tabel 1 menunjukan rekapitulasi jumlah siswa pada kelas 1, kelas 2 dan kelas 3.

Tabel 1. Rekapitulasi Data Siswa Kelas 1, Kelas 2 dan Kelas 3

\begin{tabular}{ccc}
\hline \multirow{2}{*}{ Kelas } & \multicolumn{2}{c}{ Jumlah Siswa } \\
& Laki-Laki & Perempuan \\
\hline 1 & 16 & 20 \\
\hline 2 & 24 & 27 \\
\hline 3 & 37 & 31 \\
\hline Total & $\mathbf{7 7}$ & $\mathbf{7 8}$ \\
\hline
\end{tabular}

Sumber: SD Negeri Sukarasa 2 (2021)

Untuk Data Siswa SDN Sukarasa 2 kelas 1 berjumlah 36 orang, kelas 2 sebanyak 51 orang dan kelas 3 berjumlah 68 orang, sehingga total keseluruhan siswa kelas 1-3 berjumlah 155 orang dengan jumlah laki-laki sebanyak 77 orang dan perempuan 78 orang. Metode pembelajaran selama masa pandemi dilakukan secara daring/online. Namun untuk saat ini, pembelajaran di lakukan secara luring/bergilir, untuk kelas 1, kelas 2, dan kelas 3 dilaksanakan setiap hari Senin-Rabu, untuk kelas lainnya dilaksanakan pembelajaran setiap hari Jum'at-Sabtu. Namun, seperti yang sudah dijelaskan bahwa dari adanya pembelajaran secara daring/online sebelumnya, membawa dampak yang mengkhawatirkan bagi siswa, khususnya siswa kelas 1, kelas 2, dan kelas 3. Rendahnya aspek kemampuan dalam literasi dan numerisasi menjadi hasil yang didapat selama masa pembelajaran daring yang dilakukan selama wabah pandemi memuncak. Hal tersebut mendorong kami untuk melakukan kegiatan pengabdian berupa study $c l u b$. Tujuannya adalah sebagai solusi yang dapat diterapkan atas

Rostiena Pasciana, dan kawan-kawan. Peningkatan Kualitas Membaca dan Menulis 
permasalahan yang terjadi di SDN Sukarasa 2 yaitu mengenai kurangnya kemampuan membaca dan menulis siswa yang diakibatkan kurang efektifnya pembelajaran online/daring selama pandemi covid.

\section{METODE PELAKSANAAN}

Kegiatan study club ini adalah salah satu program di bidang Pendidikan pada kegiatan Kuliah Kerja Nyata (KKN) Universitas Garut yang diselenggarakan oleh kelompok 1 Desa Sukarasa. Kegiatan ini dilaksanakan di SDN Sukarasa 2

Kecamatan Samarang Kabupaten Garut dan sasaran dalam kegiatan ini ialah siswa SD kelas 1, kelas 2 dan Kelas 3. Penentuan lokasi dan sasaran ini dilakukan berdasarkan kebutuhan yaitu sebagai solusi dari permasalahan yang terjadi seperti yang telah dijelaskan sebelumnya. Kegiatan study club ini dilakukan selama 2 kali pertemuan per minggunya selama 1 bulan dengan memanfaatkan waktu seusai waktu pelajaran rutin di sekolah dengan durasi selama 60 menit tiap pertemuannya.

Sebelum melakukan kegiatan ini, sumber data yang didapat berupa dokumen data siswa. Kemudian kami dilibatkan dalam kegiatan belajar mengajar di tiap kelas sehingga dapat melakukan pengamatan secara langsung kepada siswa kelas 1, kelas 2 dan kelas 3. Setelah itu mengidentifikasi siswa yang belum bisa membaca serta menulis dan membuat satu kelompok belajar gabungan kelas 1, kelas 2 dan kelas 3 . Untuk metode yang dilakukan dalam kegiatan study club di SDN Sukarasa 2 dalam metode membaca yaitu dengan metode bunyi, metode abjad, metode suku kata dan metode kata lembaga. Untuk metode yang digunakan dalam kegiatan menulis yaitu metode abjad dan metode kupas rangkai suku kata. Setelah selesai kegiatan study club kami mencoba mengevaluasi dan melakukan analisis mengenai hasil dari kegiatan ini.

Rostiena Pasciana, dan kawan-kawan. Peningkatan Kualitas Membaca dan Menulis Siswa Sekolah Dasar melalui Study Club 
Metode evaluasi yang digunakan dalam study club SDN 2 Sukarasa yaitu (Slamet, 2014):

1. Dengan Memberikan Naskah kepada siswa

2. Melakukan test pelafalan terhadap naskah yang diberikan

Untuk Indikator dari metode evaluasi tersebut ialah sebagai berikut :

1) Ketepatan menyuarakan tulisan

Pemberian naskah yang terdiri dari beberapa suku kata kemudian dilakukan pengarahan kepada siswa dimulai dari pengenalan hurup pengejaan setiap kata. Pada metode ini siswa diarahkan untuk membaca kata yang tersedia dalam naskah yang telah diberikan. Hal yang dinilai dari kegiatan ini yaitu ketepan siswa dalam melafalkan huruf dan kata.

2) Kewajaran Lafal

Melakukan test pelafalan huruf dan kata oleh setiap siswa sekolah dasar. Metode ini hampir sama dengan metode ketepatan menyuarakan tulisan. Indikator yang dinilai yaitu kejelasan pelafalan siswa terhadap huruf dan kata yang dilafalkan.

3) Kelancaran

Dengan ini pengajar dapat melihat sejauh mana kemampuan siswa dalam mengetahui huruf dalam setiap kata atau kalimat dengan memberikan naskah bacaan pada siswa. Dengan indikator kemudahan siswa dalam membaca suatu kata atau kalimat setelah diarahkan oleh pengajar.

4) Kejelasan Suara

Pengajar memperhatikan kejelasan suara siswa dalam membaca dengan malakukan test membaca secara mandiri setelah diarahkan.

5) Pemahaman makna kata

Pengajar melakukan evaluasi dengan memperhatikan kefahaman siswa terhadap makna kata yang diucapkan atau dibacakan.

Rostiena Pasciana, dan kawan-kawan. Peningkatan Kualitas Membaca dan Menulis Siswa Sekolah Dasar melalui Study Club 
Metode Evaluasi Menulis kepada siswa SDN Sukarasa 2 ialah sebagai berikut :

1) Menyalin tulisan

Pengajar memberikan contoh tulisan dari setiap hurup atau angka kemudian siswa diminta untuk mengulangi tulisan tersebut dengan target yang ditentukan oleh pengajar, sehingga siswa menjadi terbiasa dan lebih memahami huruf, angka, atau kata yang diberikan oleh pengajar.

2) Pengenalan Objek melalui gambar Siswa diberikan gambar suatu objek dengan nama objek tersebut, kemudian siswa diminta membaca dari nama objek tersebut,kemudian diminta menulis kembali dari nama objek yang sudah dihapus terlebih dulu. Dengan metode tersebut siswa diharapkan dapat lebih mengingat setiap huruf dan kata dengan diterapkannya metode pengenalan objek dengan gambar.
3) Melakukan dikte atau siswa diminta menulis kembali apa yang diucapkan oleh pengajar, dengan metode tersebut siswa diharapkan dapat memahami setiap susunan kata yang diucapkan oleh pengajar.

Selanjutnya dari hasil evaluasi tersebut kemudian dianalisis secara deskriptif sehingga mampu menggambarkan fenomena yang terjadi dan perubahannya (kondisi sebelum dan sesudah pelaksanaan program) sebagai gambaran hasil dari pelaksanaan kegiatan pengabdian pada masyarakat dalam program "study club" ini.

\section{HASIL DAN PEMBAHASAN}

Pandemi Covid-19 yang melanda sejak tahun 2019 hingga tahun 2021 sekarang, membawa dampak yang sangat signifikan terhadap semua aspek kehidupan, dampak besar yang ditimbulkan membuat perubahan besar dalam kebiasaan kehidupan sehari-hari, baik itu dalam bidang 
sosial, politik, budaya, ekonomi, maupun pendidikan.

Dalam dunia Pendidikan khususnya di Indonesia, adanya pandemi Covid-19 ini berdampak pada proses pembelajaran yang diberlakukan lebih khususnya kepada tingkat Sekolah Dasar (SD), sebagaimana kita ketahui bahwasannya selama pandemi Covid19 segala bentuk kegiatan pembelajaran dilakukan secara Daring (Dalam Jaringan) atau dengan kata lain segala bentuk pembelajaran yang dijalani oleh siswa dilakukan secara metode online. Dari hal tersebut timbul masalah berupa penurunan kualitas pembelajaran siswa semasa pandemi ini.

Penurunan tersebut didorong oleh kurangnya kualitas SDM dalam hal ini kemampuan orang tua dalam melakuan pembimbingan selama proses pembelajaran siswa dirumah, baik berupa ketidak mampuan atau ketidak pahaman orang tua dalam mengoperasikan teknologi yang digunakan

dalam

proses pembelajaran daring, ataupun ketidakmampuan orang tua dalam memenuhi sarana penunjang kegiatan pembelajaran secara online tersebut. Kemudian ada pula kondisi dimana kedua orang tuanya sama-sama memiliki kesibukan yang berkaitan dengan Work From Home (WFH), sehingga siswa tersebut kurang mendapatkan perhatian dan bimbingan dalam proses pembelajaran secara daring. Sementara itu, dalam pelaksanaan pembelajaran secara daring fungsi orang tua sangat diperlukan guna menunjang kelancaran kegiatan dan motivasi siswa (Nahdi et al., 2020).

Kemudian proses pembelajaran secara daring sangat dipengaruhi kualitas jaringan disuatu wilayah atau daerah, sebagaimana kita ketahui kualitas jaringan internet di negara kita masih belum dapat kita katakan sempurna, itu ditandai dari masih banyaknya wilayah atau daerah yang masih belum tersentuh oleh jaringan

Rostiena Pasciana, dan kawan-kawan. Peningkatan Kualitas Membaca dan Menulis 
internet ataupun kualitas jaringan yang sangat buruk. Yang membuat siswa terpaksa mengalami gangguan dalam melaksanakan proses pembelajaran secara daring, selain daripada itu dampak ketidak merataannya jaringan internet di Indonesia membuat siswa-siswa dibeberapa tempat harus terpaksa berjalan jauh bahkan sampai mendaki gunung untuk mendapatkan jaringan untuk melaksanakan proses pembelajaran secara daring.

Selain daripada itu penurunan kualitas pebelajaran siswa didorong oleh kondisi siswa yang akan cepat merasa bosan dan jenuh dalam melaksanakan proses pembelajaran secara online, hal itu dikarenakan mereka kurang melakukan interaksi sosial bersama teman sebayanya, dan hanya dihadapkan pada gadget. Kemudian masalah lainnya pun muncul ketika siswa sudah merasa jenuh, maka siswa akan cenderung tergoda menggunakan gadget sebagai hiburan dan mengesampingkan proses pembelajaran.

Dalam studi kasus yang terjadi di SDN Sukarasa 2 Kabupaten Garut Kec. Samarang, selama masa pandemi Covid-19 pembelajaran dilakukan scara daring/online sehingga mengharuskan siswa melakukan pembelajaran lewat Gadget/teknologi lainnya. Namun tidak semua siswa memiliki alat penunjang belajar online/daring, sehingga hal ini menjadi suatu kendala dan juga keterbatasan akses jaringan yang tidak stabil membuat akses pembelajaran menjadi sulit. Namun setelah masa pandemi mereda, pembelajaran dilakukan secara luring dengan membagi jadwal pembelajaran per kelas.

Dampak dari pembelajaran selama online/daring ini membuat aspek perkembangan membaca dan menulis siswa mengalami penurunan serta tidak berkembang. Kurangnya arahan serta bimbingan dari orang tua dan juga keterbatasan SDM dalam 
mengoperasikan teknologi selama masa pembelajaran daring/online dirasa menjadi salah satu faktor lain yang menjadi hambatan dalam perkembangan membaca dan menulis siswa. Rendahnya kemampuan siswa serta tidak berkembang dalam melakukan membaca dan menulis menjadi suatu masalah bagi guru serta pihak sekolah, pasalnya Sekolah Dasar memiliki tujuan dalam mencapai standar kompetensi bagi siswa untuk difokuskan pada penanaman karakter yang sesuai dengan nilai-nilai Pancasila serta kompentensi literasi dan numerasi peserta didik.

Sekolah dasar sebagai Lembaga Pendidikan Formal diharapkan dapat menangani berbagai macam kesulitan anak dalam membaca dan menulis serta diharapkan dapat meningkatkan kemampuan dan keterampilan berbahasa. Untuk masalah seperti kesulitan dalam membaca dan menulis seringkali kurang mendapat perhatian dari guru, sebagian tenaga pendidik (guru) cenderung belum bisa memahami sepenuhnya siswa yang memang kesulitan dalam belajar membaca dan menulis (Meo et al., 2021). Kegiatan ini dilakukan untuk membantu dalam mendapatkan satu solusi atas permasalahan terjadi, dengan langsung turun ke lapangan dan mengamati dalam proses belajar dan mengajar di SDN Sukarasa 2, objek sasaran dalam penelitian ini pada kelas 1, kelas 2, dan kelas 3 . Informasi mengenai objek penelitian ini didapat berdasarkan informasi dari guru sekolah atas rendahnya perkembangan membaca dan menulis siswa. Untuk informasi data, tersaji pada tabel 2 berikut ini:

Tabel 2. Rekapitulasi Data Siswa yang Terkendala dalam Membaca dan Menulis

Jumlah

Siswa

\begin{tabular}{|c|c|c|}
\hline Kelas & $\begin{array}{c}\text { Jumlah } \\
\text { Siswa }\end{array}$ & $\begin{array}{l}\text { Terkendala } \\
\text { dalam }\end{array}$ \\
\hline & L & $\begin{array}{c}\text { Membaca } \\
\text { Dan }\end{array}$ \\
\hline
\end{tabular}

\begin{tabular}{ccccc}
\multicolumn{4}{c}{ Menulis } \\
\hline 1 & 16 & 20 & 22 & $61 \%$ \\
\hline 2 & 24 & 27 & 14 & $27 \%$ \\
\hline 3 & 37 & 31 & 6 & $9 \%$ \\
\hline Total & $\mathbf{7 7}$ & $\mathbf{6 3}$ & $\mathbf{4 2}$ & $\mathbf{2 7 \%}$ \\
\hline
\end{tabular}

Sumber: SDN Sukarasa 2 (2021)

Rostiena Pasciana, dan kawan-kawan. Peningkatan Kualitas Membaca dan Menulis Siswa Sekolah Dasar melalui Study Club 
Dalam memecahkan masalah tersebut kelompok kami membuat inovasi berupa pelaksanaan kegiatan study club. Secara umum yang dimaksud dengan study club ialah suatu kelompok belajar yang bertujuan untuk membahas kembali materi pembelajaran yang belum dipahami (Solahudin, 2018). Diadakannya program Study Club yang memiliki tujuan untuk membantu guru dan mempercepat proses perkembangan kemampuan siswa dalam membaca dan menulis. Untuk metode belajar dalam program Study Club ini menggunakan metode abjad, Metode KRKS (Kupas Rangkai Suku Kata), Metode Bunyi, dan Metode Kata Lembaga. Untuk proses kegiatan Study Club di SDN Sukarasa 2 tersaji dalam gambar 1 berikut:
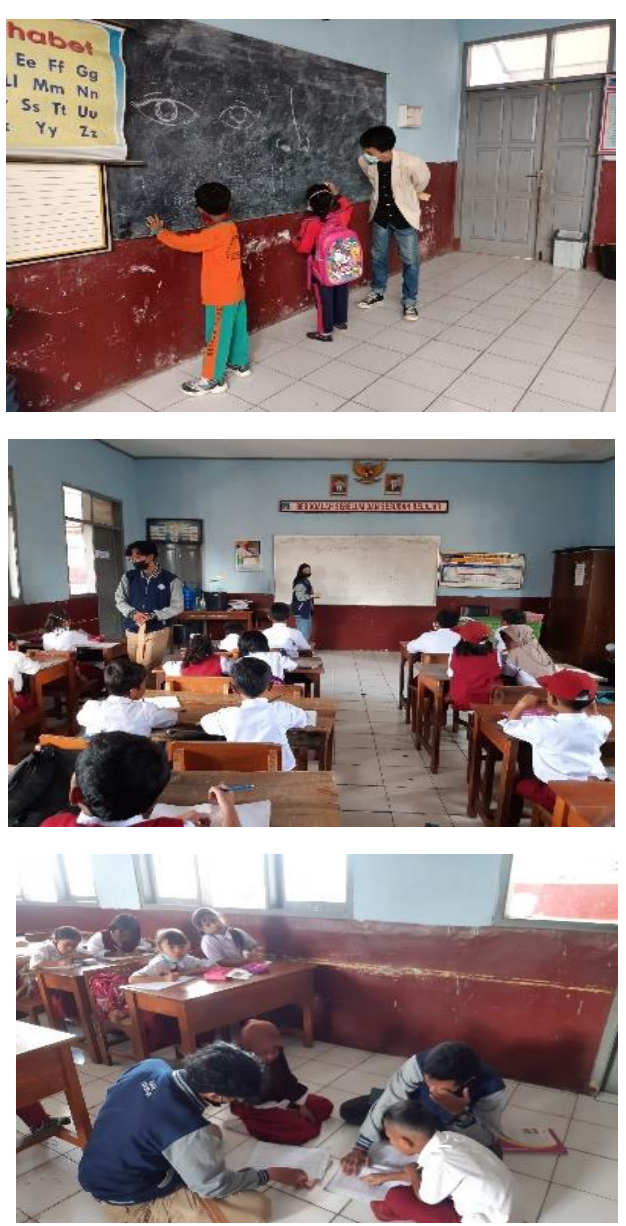

Gambar 1 Proses Pelaksanaan Kegiatan Study Club

Sumber: Dokumentasi Kelompok 2021

Dalam membaca metode yang digunakan diantaranya yaitu:

Metode Bunyi, metode ini dilakukan dengan cara mengenalkan huruf a sampai huruf $\mathrm{z}$ beserta cara pengucapannya.

Dalam penerapannya, metode ini dilakukan dengan proses latihan terus menerus. Seperti contoh : huruf $\mathrm{p} /$

Rostiena Pasciana, dan kawan-kawan. Peningkatan Kualitas Membaca dan Menulis Siswa Sekolah Dasar melalui Study Club 
dilafalkan (ep), huruf d/ dilafalkan (ed), dengan demikian untuk mengeja kata padi dapat dieja menjadi ; /epa/(pa)/ed-i/(di) dibaca (padi) (Muhyidin et al., 2018).

(2) Metode suku kata, metode ini dilakukan dengan cara memberikan pengenalan terhadap suku kata dasar seperti ba, bi bu, be, bo, ca, ci, cu, ce, co, $d a, d i, d u, d e, d o$, dan seterusnya, yang kemudian suku kata tersebut disatukan menjadi membentuk suatu kata, seperti bi - bi/, ca - ci/, da - da (Muhyidin et al., 2018).

(3) Metode kata lembaga, ialah suatu metode peralihan antara metode global dan metode bunyi. Dimulai dari materi ajar dari kata yang dekat dengan siswa, dipahami, dan sering didengar. Karena dalam konsep ini pada dasarnya, materi ajar itu berbentuk dalam gambar dan nama gambar di bawahnya. Misalkan gambar wajah, ataupun anggota tubuh. Dibawah gambar anggota tubuh tadi ditulis kata tangan, kaki, jari tangan dan lain-lain. Adapun tahapannya yaitu (a) Kata yang akan digunakan diuraikan menjadi suku kata, (b) Suku kata tersebut kemudian diuraikan menjadi huruf, (c) Huruf itu kemudian di rangkai menjadi suku kata kembali, 4. Suku Kata itu dirangkaikan menjadi kata dan dirangkaikan menjadi satu kalimat (Muhyidin et al., 2018).

(4) Metode abjad, metode ini dilakukan dengan cara memperkenalkan huruf alfabet yang kemudian dilafalkan dan dihafalkan. Melalui metode ini juga dibedakan antara huruf yang memiliki kemiripan bentuk seperti halnya huruf /b-d/, /m$\mathrm{n} /$, /p-q/ yang kemudian dihafalkan dan ditanyakan kembali kepada siswa (Muhyidin et al., 2018).

Adapun metode menulis yang digunakan diantaranya (1) Metode Abjad yang dapat dikatakan juga sebagai metode sintetis karena mempelajari huruf/aksara dengan cara merangkai huruf yang dilafalkan dalam abjad. Untuk langkah yang dilakukan dalam melaksanakan

Rostiena Pasciana, dan kawan-kawan. Peningkatan Kualitas Membaca dan Menulis 
pembelajaran menulis dengan metode abjad sebagai berikut: 1. Pengenalan bentuk huruf dari a sampai huruf $\mathrm{z}$ satu persatu; 2. Penulisan berulang abjad secara berurutan sampai siswa mengenal huruf abjad; 3. Setelah siswa mengenal semua abjad, kemudian melakukan perangkaian menjadi satu suku kata (Muhyidin et al., 2018).

(2) Metode KRSK (Kupas Rangkai Suku Kata) merupakan suatu cara yang memiliki dasar pada pendekatan harfiah. Dalam pengajaran, dimulai dengan cara menulis dari mengenalkan huruf-huruf yang terangkai dalam satu suku kata yang kemudian menjadi kata. Untuk Langkah dimulai mengenalkan terlebih dahulu huruf lepas, kemudian merangkai menjadi suatu suku kata. Lalu dirangkaikan suku kata tersebut menjadi suatu kata (Muhyidin et al., 2018).

Proses Kegiatan Study Club ini dilaksanakan selama 2 pertemuan per minggu selama 1 bulan, proses kegiatan ini mendapat apresiasi penuh dari guru yang ada di sekolah dasar, pasalnya dengan kegiatan Study Club ini sangat membantu sekali terhadap guru kelas dalam proses memperlancar kemampuan siswa dalam membaca dan menulis. Perkembangan siswa dalam membaca dan menulis setelah adanya kegiatan Study Club ini mengalami kenaikan yang cukup signifikan. Untuk data perkembangan siswa, dapat dilihat pada gambar 2 berikut:

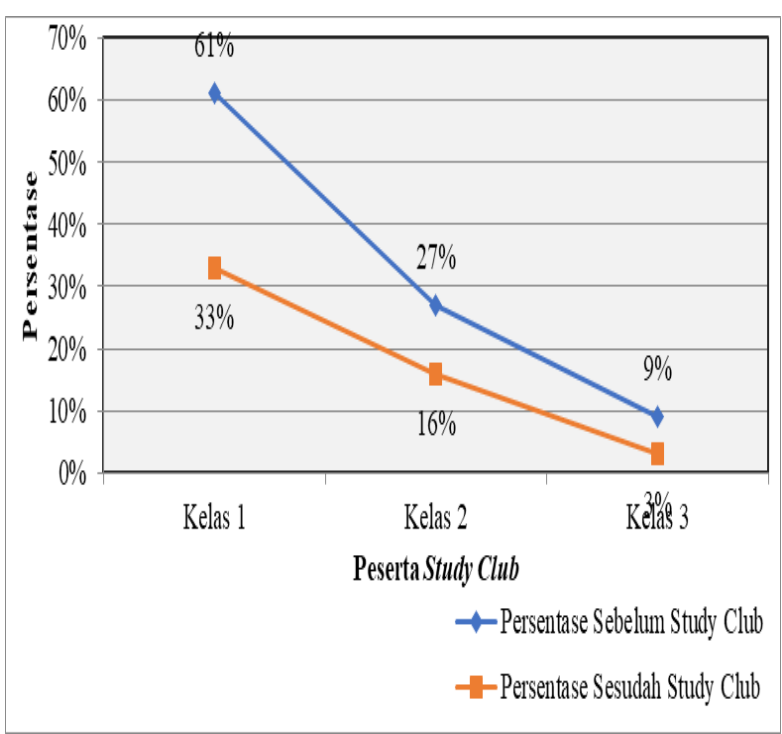

Gambar 2 Progress Perkembangan Siswa yang Terkendala dalam Membaca dan Menulis Sumber: Hasil Olah Peneliti (2021)

Rostiena Pasciana, dan kawan-kawan. Peningkatan Kualitas Membaca dan Menulis Siswa Sekolah Dasar melalui Study Club 
Gambar 2 menunjukkan progres dari hasil kegiatan study club. Dari gambar 2 tersebut dapat diketahui bahwa baik itu kelas 1, kelas 2 ataupun kelas 3 telah terjadi penurunan siswa yang terkendala dalam proses membaca dan menulis. Angka penurunan yang paling tinggi terjadi pada kelas 1 yakni sebesar $28 \%$ atau sekitar 10 orang. Maka dapat dikatakan bahwa sejauh ini penerapan program kegiatan Study Club ini mampu memberikan dampak yang baik dalam perkembangan kemampuan siswa dalam membaca dan menulis.

\section{KESIMPULAN DAN SARAN}

Pandemi Covid-19 memang membawa dampak yang sangat signifikan terhadap berbagai aspek kehidupan, terutama dalam bidang pendidikan. Dengan diadakannya program kegiatan berupa Study Club kepada siswa SDN Sukarasa 2 khususnya pada kelas 1, kelas 2 dan kelas 3 membawa dampak positif serta memberikan penurunan terhadap angka siswa yang sebelumnya belum bisa membaca dan menulis menjadi lancar dalam membaca dan menulis.

Untuk itu diharapkan program Study Club ini dapat tetap berjalan/ dilakukan secara berkelanjutkan oleh pihak SDN Sukarasa 2, dengan metode pelaksanaan pengajaran dan evaluasi seperti yang telah dilakukan selama ini. Selain itu diharapkan agar siswa yang belum lancar dalam membaca dan menulis diberikan motivasi dan perhatian khusus dari guru serta kerjasama dari orang tua siswa untuk senantiasa berlatih karena membaca dan menulis merupakan satu aspek yang menjadi standar kompetensi jenjang pendidikan dasar.

Rostiena Pasciana, dan kawan-kawan. Peningkatan Kualitas Membaca dan Menulis Siswa Sekolah Dasar melalui Study Club 


\section{REFERENSI}

Alawiyah, A. R., Mulyana, E. H., \& Apriliya, S. (2018). Model Inkaber Sebagai Inovasi Pembelajaran Untuk Meningkatkan Keterampilan Membaca Menulis Permulaan Siswa Sekolah Dasar. PEDADIDAKTIKA: Jurnal Ilmiah Pendidikan Guru Sekolah Dasar, 5(2), 141-151. http://ejournal.upi.edu/index.ph $\mathrm{p} /$ pedadidaktika/index

Ariesca, Y., Dewi, N. K., \& Setiawan, H. (2021). Analisis Kesulitan Guru Pada Pembelajaran Berbasis Online Di SDN Se-Kecamatan Maluk. Progres Pendidikan, 2(1), 20-25.

https://doi.org/10.29303/prospek. v2i1.86

Handayani, L. (2020). Peningkatan Motivasi Belajar IPA Melalui Model Pembelajaran Project Based Learning pada Masa Pandemi Covid-19 bagi Siswa SMP Negeri 4 Gunungsari. Jurnal Paedagogy:Jurnal Penelitian Dan Pengembangan Pendidikan, 7(3). https://doi.org/10.33394/jp.v7i3.2 726

Meo, A., Wau, M. P., \& Lawe, Y. U. (2021). Analisis Kesulitan Belajar Membaca Permulaan Pada Siswa Kelas I Sdi Bobawa Kecamatan Golewa Selatan Kabupaten Ngada. Jurnal Citra Pendidikan, 1(2), 277-287. http://jurnalilmiahcitrabakti.ac.id /jil/index.php/jcp/index Muhyidin, A., Rosidin, O., \& Salpariansi, E. (2018). Metode Pembelajaran Membaca Dan Menulis Permulaan Di Kelas Awal. Jurnal Pendidikan Sekolah Dasar, $\quad 4(1), \quad 30$. https://doi.org/10.30870/jpsd.v4i1 .2464

Nahdi, K., Ramdhani, S., Yuliatin, R. R., \& Hadi, Y. A. (2020). Implementasi Pembelajaran pada Masa Lockdown bagi Lembaga PAUD di Kabupaten Lombok Timur. Jurnal Obsesi: Jurnal Pendidikan Anak Usia Dini, 5(1), 177-186.

https://doi.org/10.31004/obsesi.v5 i1.529

Pamungkas, D. E., \& Sukarman, S. (2020). Transformasi Dunia Pendidikan Di Sekolah Dasar Dalam Masa Pandemi Covid-19. Jurnal Review Pendidikan Dasar: Jurnal Kajian Pendidikan Dan Hasil Penelitian, 6(3). http://journal. unesa.ac.id/index.php/PD

PPRI. (2021). Peraturan Pemerintah Republik Indonesia Nomor 57 Tentang Standar Nasional Pendidikan. 102501, 1-49.

Setiono, P., Handayani, E., Selvia, S., \& Widian, W. (2020). Strategi Guru Dalam Pembelajaran Daring Pada Masa Covid-19 Di Sekolah Dasar. JURIDIKDAS: Jurnal Riset

Rostiena Pasciana, dan kawan-kawan. Peningkatan Kualitas Membaca dan Menulis Siswa Sekolah Dasar melalui Study Club 
Pendidikan Dasar, 3(3), 402-407.

Slamet, S. Y. (2014). Pembelajaran

Bahasa dan Sastra Indonesia di

Kelas Rendah dan Kelas Tinggi

Sekolah Dasar.

Solahudin, M. (2018). Speaking Addict

(Uta (ed.)). Noktah.

Yusrizal, Y., Lubis, B. S., Fatmawati,

F., \& Muzdalifah, D. (2020).

Pengaruh Metode Visit Home

Dan Pola Bimbingan Orang Tua

Terhadap Motivasi Belajar Siswa

Sekolah Dasar Di Era Pandemi

Covid-19. Jurnal Tematik, 10(3),

129-135. https://jurnal.unimed.

ac.id/2012/

Rostiena Pasciana, dan kawan-kawan. Peningkatan Kualitas Membaca dan Menulis 